\title{
Effect of snow cover evolution on pore water pressure behaviour in embankments and cut slopes: Field observations
}

\author{
Satoshi Nishimura ${ }^{\text {i }}$, Keisuke Sasahara ${ }^{\text {ii) }}$ and Tatsuya Ishikawa ${ }^{\text {iii }}$
}

\begin{abstract}
i) Associate professor, Faculty of Engineering, Hokkaido University, Kita-13 Nishi-8, Kita-Ku, Sapporo, 060-8628, Japan. ii) Post-graduate student, Graduate School of Engineering, Hokkaido University, Kita-13 Nishi-8, Kita-Ku, Sapporo, 060-8628, Japan. iii) Professor, Faculty of Engineering, Hokkaido University, Kita-13 Nishi-8, Kita-Ku, Sapporo, 060-8628, Japan.
\end{abstract}

\begin{abstract}
Snow cover melting leads to a release of stored winter-time precipitation over a relatively short period of time and thus affects the stability of embankment and cut slopes. Capturing the patterns of pore water pressure responses against the snow melt water infiltration and reflecting them into seepage flow analysis and mechanical stability analysis may lead to more precise assessment of the spring-time instability peculiar to snowy cold regions. This paper describes lessons from the authors' experience in monitoring snow and ground conditions in three sites in Hokkaido, which were with limited access during winter. From long-term observation spanning up to 5 years, patterns and features in the snow cover evolution and ground responses are summarised. A correlation was found between the peak snow cover depth and the delay in slope surface pore water pressure responses, which represents the significant time required for melted snow to travel through the snow beneath. Reflecting this delay could lead to more precise spring-time pore water pressure assessment in slopes.
\end{abstract}

Keywords: snow, slope stability, seepage flow, embankment, cold-region engineering

\section{INTRODUCTION}

Cold regions receive a significant part of annual precipitation in form of snow, which is released at the end of winter. This temporary storage of precipitation over the ground surface has considerable effects on the pore water pressure patterns of the ground beneath, and thus affects mechanical stability of slopes. While the degree of significance may depend on regions, Hokkaido area in northern Japan has had its share of incidents reported for decades (e.g. Ishikawa, 2015; Aoki et al., 2019; Takayanagi et al., 2019). One of the most prominent cases is failure of a road embankment at Nakayama Passway along Route 230, due to snow melt water infiltration, occurring in May 2012 and April 2013. The embankment had been built some 45 years earlier, without a sign of instability since. This incident suggests a fine balance of snow melt water supply and shear resistance upon which the earth structures in cold regions rest.

The authors have been monitoring pore water pressure behaviour in a various form of earth structures with slopes, such as road embankments, cut-slopes and river dykes, and attempting to capture dominant mechanisms involved in rain/snow water infiltration, vegetation effects, and their implications to mechanical stability (Nishimura et al. 2016; Nguyen et al., 2019) in Hokkaido through numerical analysis. The analysis involved multi-phase (air/water or liquid water/ice; Nishiie et al., 2019; Subramanian et al., 2019) seepage flow computation with modelled surface processes such as snow accumulation and snow melt as boundary conditions, either with home-grown or commercially available finite element codes. The most commonly adopted method of applying the snow melt water flux to the surface involves converting the snow depth reduction to water influx by assuming a constant snow density (e.g. GEO-SLOPE International Ltd., 2019; The SoilVision Systems, Ltd., 2019). The snow depth reduction may be either measured or estimated. Given the extreme complexity involved in snow melt, including energy/mass balances and water conductivity/ retentivity, it is commonly estimated based on air temperature by rule-of-thumb approaches such as the degree-day method (e.g. Anderson, 1976; Kuushisto, 1980). However, the snow depth estimation methods are usually derived with data from flat areas, and a question remains to how snow accumulates on slopes with different conditions (slope angle, canopy, etc.). Another issue is a possible delay of infiltration and ground responses against snow depth reduction. This paper presents lessons from the authors' experience in monitoring snow and ground conditions in three sites in Hokkaido, each representing an expressway embankment, expressway cut-slope and flood-defense 
dyke. Access to these sites was severely limited during winter, and a robust monitoring system needed to be devised to endure snow burial and down-slope snow loads. From long-term observation spanning up to 5 years, lessons in estimating the snow cover depth on slope surfaces are summarised. A particular attention was paid to time delay of snow melt water in reaching the ground surface.

\section{SITE DESCRIPTION}

Three sites in Hokkaido are considered in this paper, where full or partial on-site snow depth records are available. The locations are mapped in Figure 1 and main climate statistics from nearby JMA AMeDAS weather stations are summarised in Table 1. The Kitahiroshima site, shown in Figure 2, is an expressway embankment built with volcanic sand/silt around 1970 . The embankment appears to be heterogeneous and contains occasional gravel seams. Monitoring of the snow depth and soil moisture/pore water pressure conditions was initiated in 2016. The Kuromatsunai site is an expressway highway cut-slope consisting of relatively uniform and thick volcanic sand/silt layer (Setana Formation). As shown in Figure 3, the slope is relatively steep (1:1.2) and long, divided into 4 sub-slopes. This site was particularly difficult to access during winter periods. The Naganuma site, depicted in Figure 4, is a vast flood-control site surrounded by dyke to function as a temporary buffer reservoir during flood. The $6 \mathrm{~m}$-high dyke was made of artificially mixed sand and clay in a uniform manner. Two monitoring points were set-up at diametrically opposite parts of the site, which are about $2 \mathrm{~km}$ apart. The site conditions at Naganuma are described more in detail in Nishimura et al. (2015).

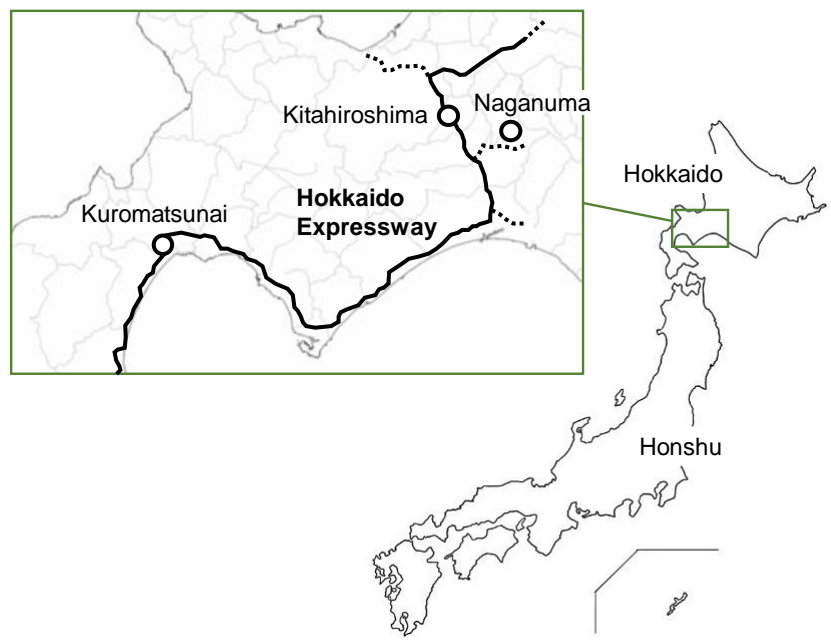

Fig. 1. Three locations of field monitoring sites.
Comparison between these sites is interesting because, despite their broadly same annual air temperature conditions, the expected snow fall amount and peak snow depth are significantly different between them, as shown in Table 1. The significant difference in the slope angles is also important in interpreting the difference between the AMeDAS snow cover depth data and the actually measured on the slopes surfaces.

Table 1. Summary of climate data recorded at AMeDAS weather stations in the vicinity of monitoring sites.

\begin{tabular}{lccc}
$\begin{array}{l}\text { 5-year data } \\
(2014-2018)\end{array}$ & $\begin{array}{c}\text { Kita- } \\
\text { hiroshima } \\
* 1\end{array}$ & $\begin{array}{c}\text { Kuro- } \\
\text { matsunai } \\
* 2\end{array}$ & $\begin{array}{c}\text { Naganuma } \\
* 3\end{array}$ \\
\hline $\begin{array}{l}\text { Annual precipi- } \\
\text { tation (mm) }\end{array}$ & 1119 & 1576 & 1022 \\
$\begin{array}{l}\text { Annual snowfall } \\
\text { (mm) }\end{array}$ & 4536 & 6758 & 2236 \\
$\begin{array}{l}\text { Maximum snow } \\
\text { cover (mm) }\end{array}$ & 764 & 1448 & 528 \\
$\begin{array}{l}\text { Annual ave. } \\
\text { temperature }\left({ }^{\circ} \mathrm{C}\right)\end{array}$ & 7.3 & 7.6 & 7.5 \\
$\begin{array}{l}\text { Annual max. } \\
\text { temperature }\left({ }^{\circ} \mathrm{C}\right)\end{array}$ & 32.6 & 32.6 & 31.6 \\
$\begin{array}{l}\text { Annual min. } \\
\text { temperature }\left({ }^{\circ} \mathrm{C}\right)\end{array}$ & -23.7 & -20.5 & -22.4 \\
\hline
\end{tabular}

*1 AMeDAS Eniwa-Shimamatsu, $7.8 \mathrm{~km}$ from the site

*2 AMeDAS Kuromatsunai, $10.7 \mathrm{~km}$ from the site

*3 AMeDAS Chitose, $16.6 \mathrm{~km}$ from the site
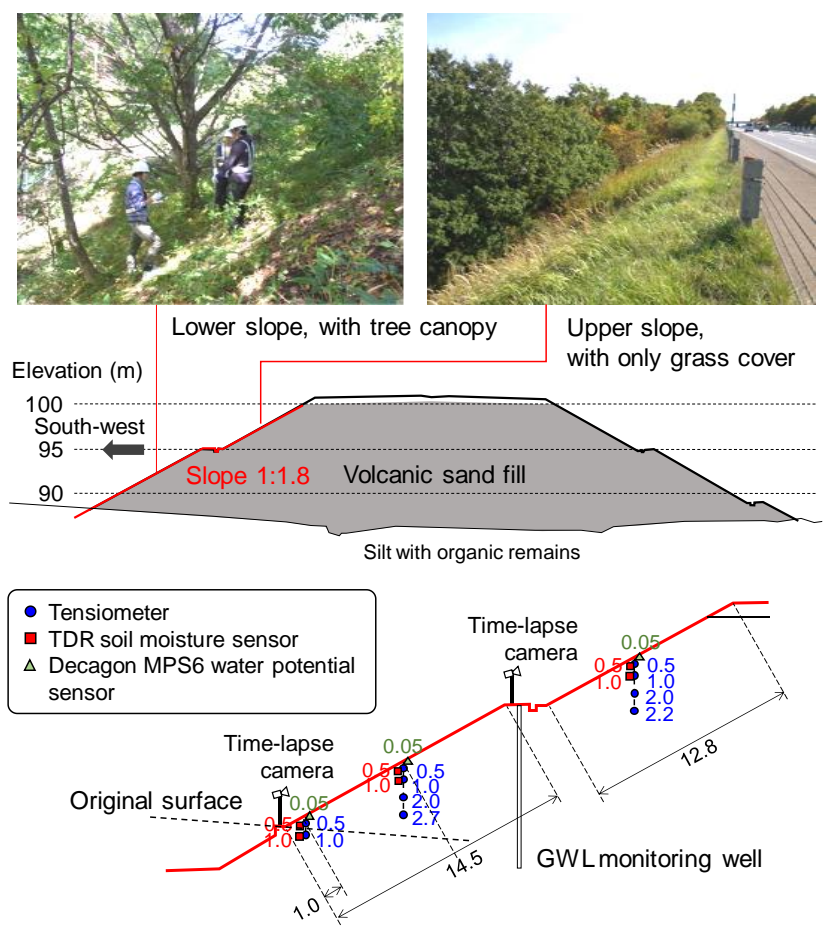

Fig. 2. Cross-section of embankment at Kitahiroshima site (values indicate depth and length in $\mathrm{m}$ ). 


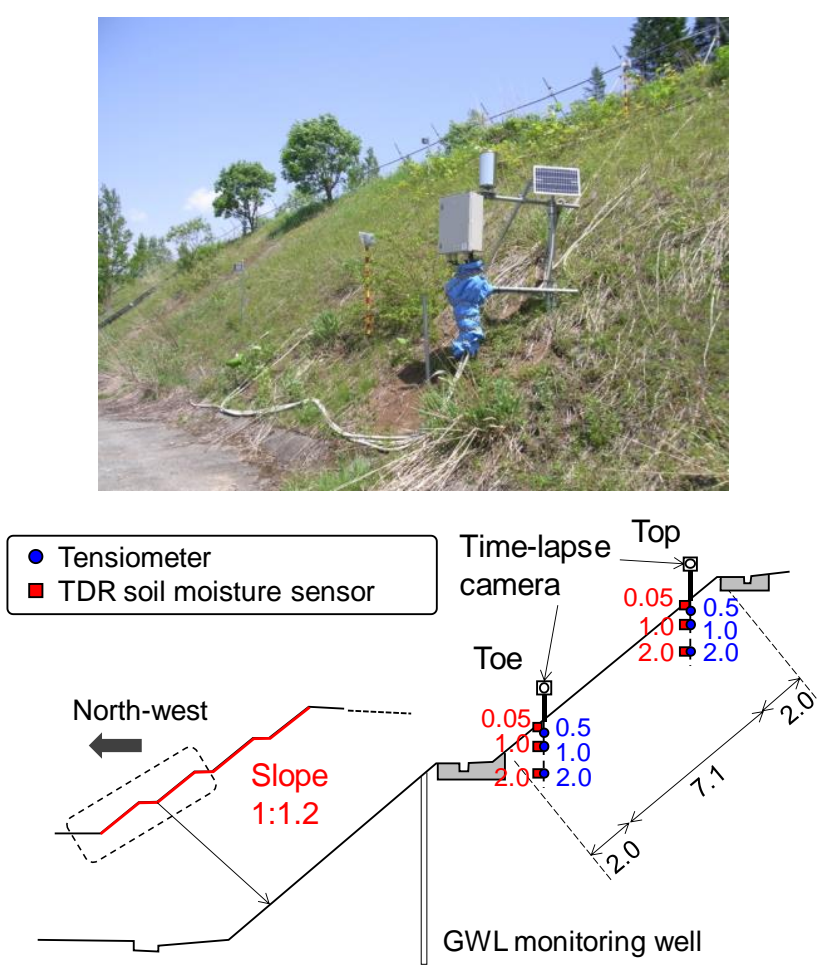

Fig. 3. Cross-section of cut-slope at Kuromatsunai site (values indicate depth and length in m: Photograph shows the second slope from the bottom).
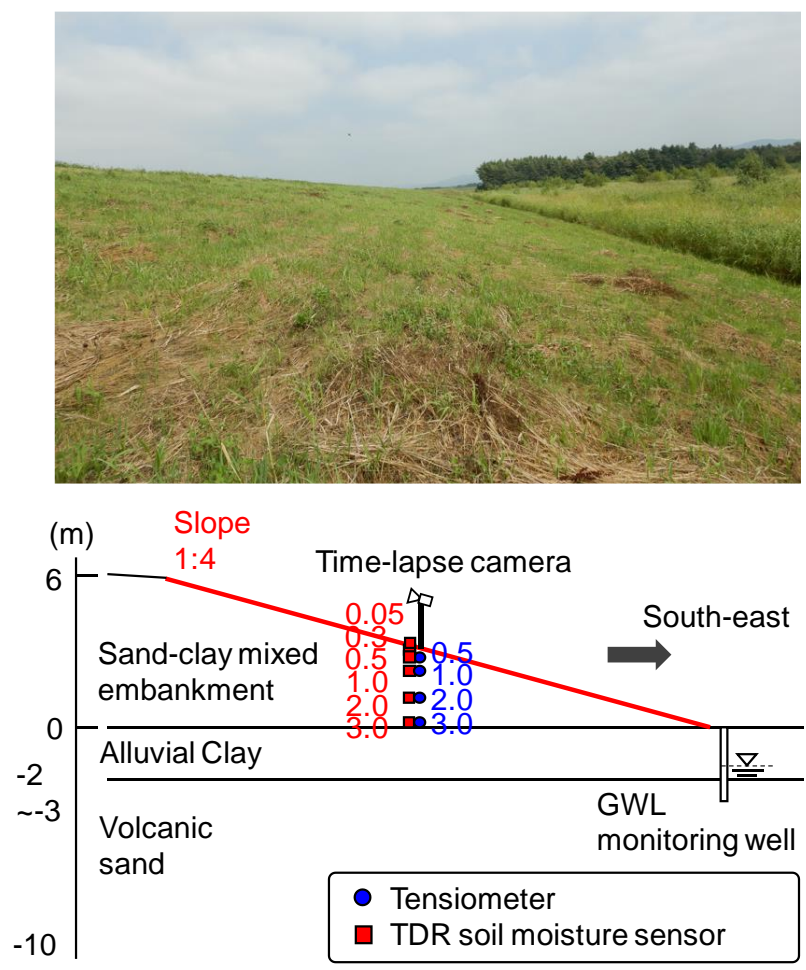

Fig. 4. Cross-section of dyke at Naganuma site 1 (values indicate depth in $\mathrm{m}$ : Site 2 is similar but facing west).

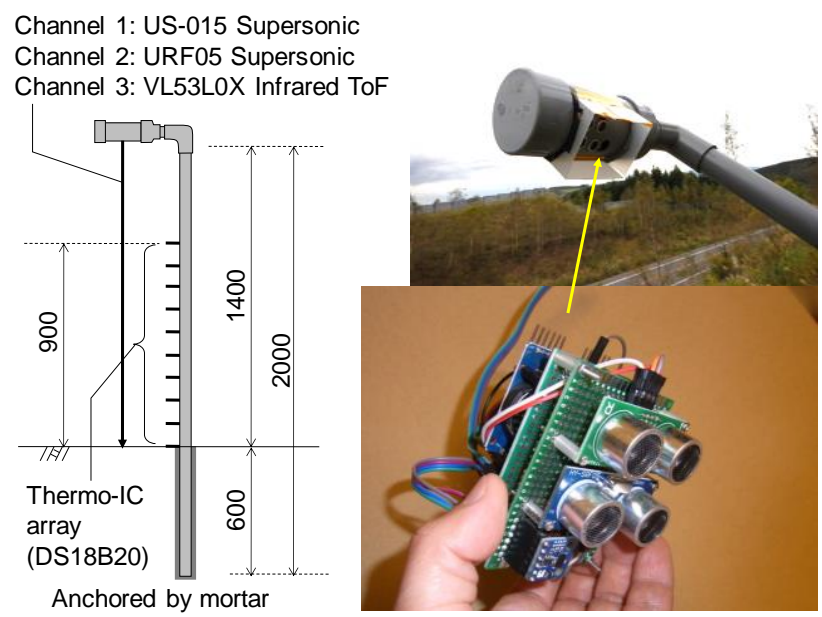

Fig. 5. New snow gauge system with multiple sensing mechanisms.
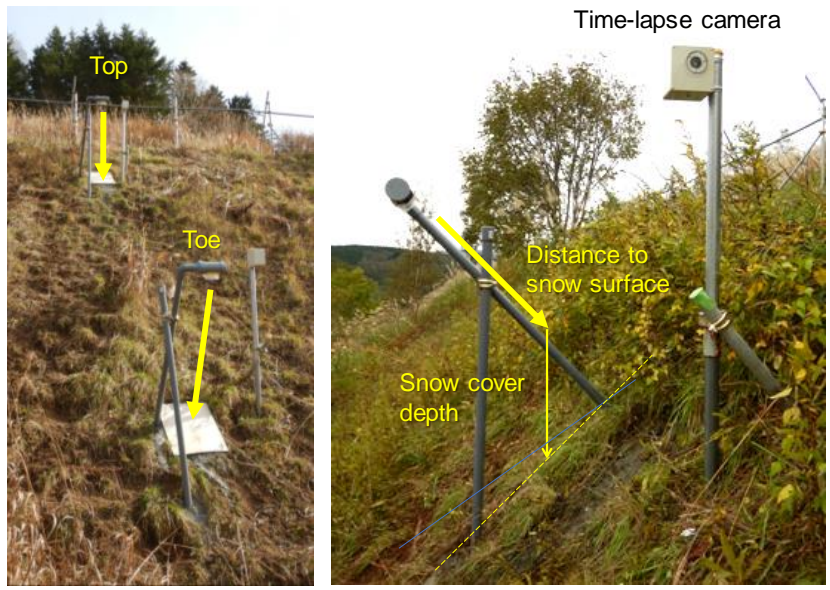

Fig. 6. Deployment of snow gauges at Kuromatsunai site.

\section{MONITORING SYSTEMS}

The instrumentation at each site is illustrated in Figures 2 through 4 . The systems typically included vertical arrays of tensiometer and soil moisture sensors. TDR soil moisture sensors or water potential sensors (Decagon MPS-6), which are considered more robust against freezing than tensiometers, were deployed at the ground surface (typically $0.05 \mathrm{~m}$ deep, in the vegetation layer) to detect surface moisture changes. The readings were recorded every 1 hour. The monitoring started from November 2017, September 2016 and August 2014 at Kitahiroshima, Kuromatsunai and Naganuma sites, respectively.

The snow gauges in various forms and principles have been deployed at each site. At the Naganuma site, the system was simplest and consisted of a time-lapse digital camera and a pole with depth markings, set up at the middle of the slope. The slope at this site was gentle (1:4) and no significant variation of snow thickness was observed across the slope. The system was enhanced at the Kitahiroshima site, where two cameras and eight gauge poles were installed. With multiple sub-slopes 
Table 2. Advantages and disadvantages of snow gauge systems based on different sensors.

\begin{tabular}{|c|c|c|c|c|}
\hline Sensor & Principle & Advantages & Disadvantages & $\begin{array}{l}\text { Approx. } \\
\text { cost* }\end{array}$ \\
\hline $\begin{array}{l}\text { Interval } \\
\text { camera }\end{array}$ & $\begin{array}{l}\text { Observing gauge } \\
\text { poles and reading } \\
\text { out snow cover } \\
\text { depth from images }\end{array}$ & $\begin{array}{l}\text { Spatial distribution of snow } \\
\text { depth can be recorded with } \\
\text { multiple gauge poles } \\
\text { Most reliable, with images left. } \\
\text { Ground conditions can be } \\
\text { observed }\end{array}$ & $\begin{array}{l}\text { Does not work during night } \\
\text { Vision occasionally lost with snow } \\
\text { attached to lens or by snow burial } \\
\text { Telecommunication of data difficult } \\
\text { (requiring large data transfer) } \\
\text { Snow cover depth needs to be read out } \\
\text { from images } \\
\text {. Relatively large power consumption }\end{array}$ & $\begin{array}{c}30,000 \text { JPY } \\
\text { (280 USD) }\end{array}$ \\
\hline $\begin{array}{l}\text { Infrared } \\
\text { time-of- } \\
\text { flight } \\
\text { sensor } \\
\end{array}$ & $\begin{array}{l}\text { Measuring the } \\
\text { distance to snow } \\
\text { surface }\end{array}$ & $\begin{array}{l}\text { Recorded as single value and } \\
\text { easy to send data by } \\
\text { telecommunication } \\
\text { Low power consumption }\end{array}$ & $\begin{array}{l}\text { Signal difficult to detect in strong } \\
\text { daylight } \\
\text { - Snow cover at only one location } \\
\text { - Sensor rig prone to large external forces }\end{array}$ & $\begin{array}{l}\text { 4,000 JPY } \\
\text { (37 USD) }\end{array}$ \\
\hline $\begin{array}{l}\text { Ultrasonic } \\
\text { wave } \\
\text { distance } \\
\text { transducer }\end{array}$ & $\begin{array}{l}\text { Measuring the } \\
\text { distance to snow } \\
\text { surface }\end{array}$ & $\begin{array}{l}\text { Recorded as single value and } \\
\text { easy to send by } \\
\text { telecommunication } \\
\text { Low power consumption }\end{array}$ & $\begin{array}{l}\text { - Signal difficult to detect when snow } \\
\text { surface is very soft } \\
\text { - Snow cover at only one location } \\
\text { - Sensor rig prone to large external forces }\end{array}$ & $\begin{array}{c}3,000 \text { JPY } \\
\text { (28 USD) }\end{array}$ \\
\hline $\begin{array}{l}\text { Thermo- } \\
\text { meter } \\
\text { array }\end{array}$ & $\begin{array}{l}\text { Detecting snow } \\
\text { cover by damped } \\
\text { response of } \\
\text { thermometer against } \\
\text { air temperature } \\
\text { variations }\end{array}$ & $\begin{array}{l}\text { Recorded as small data array and } \\
\text { easy to send by } \\
\text { telecommunication } \\
\text { Snow state and evolution can be } \\
\text { studied from temperature } \\
\text { profiles } \\
\text { Low power consumption } \\
\text { Snow burial-proof }\end{array}$ & $\begin{array}{l}\text { Discrete data with low vertical spatial } \\
\text { resolution (corresponding to } \\
\text { thermometer intervals) } \\
\text { - Snow cover at only one location }\end{array}$ & $\begin{array}{l}\text { 4,000 JPY } \\
\text { (37 USD) }\end{array}$ \\
\hline
\end{tabular}

*In this project: Inclusive of data logger and attachments, not inclusive of assembling fees

and relatively long slope length, a significant difference was seen across the slopes. At the Kutomatsunai site, a more elaborate system, newly developed for this project, was adopted since 2017 in addition to two time-lapse cameras and two gauge poles, installed at the top and toe of the second slope, as illustrated in Figure 3. The new snow gauge has three surface detection sensors; one infrared Time-of-Flight (ToF) sensor and two ultrasonic wave distance sensors with different processing chips (US-015 and URF05); see Figure 5. In the same system, an array of 10 themo-ICs was installed, of which records were used to estimate the period during which each of them was buried under snow, as detected by disappearance of diurnal variations due to the snow insulation effect. The arrangement of the two gauges, each at the top and toe of the slope, is shown in Figure 6.

The advantages and disadvantages of different snow cover depth measurement methods are summarised in Table 2 based on the authors' experience. Although detecting the snow cover itself is not particularly difficult, no single method is omnipotent and totally reliable. As this study will find out, snow cover depth can be very non-uniform across steep slopes. Real-time acquisition of snow cover depth at slopes is useful as part of early-warning system for instability. For a snow gauge to be ubiquitous, the data must be transferable on air and low-cost. An optimum design that satisfies this requirement while being care-free, is still being sought. An important benefit of the thermometer array is that it can be used to confirm the state of the ground surface.
In the present study, the ground surface remained unfrozen during winter, except for short periods in early winter in some years.

\section{SNOW COVER EVOLUTION AND PORE WATER PRESSURE REPONSES IN SLOPES}

\subsection{Snow cover evolution}

A typical time-history of snow cover depth measured over single winter period is shown for each of the three sites in Figure 7. Also shown in the figure are data from nearby AMeDAS weather stations (see Table 1 footnotes). From these and other years' data, the following general trends were seen; the shapes/patterns of the snow depth - time curves are similar for a particular site during a particular winter, regardless of which part of slope. The snow cover peak was attained on a same day at all the parts of slope as the AMeDAS stations. However, the magnitude of the snow cover is very non-uniform across each slope, due to different reasons. Generally, snow tends to move towards the slope's toe when a certain thickness is reached; approximately $0.3 \mathrm{~m}$ in Kuromatsuai's case, as seen in December in the shown example. The images from the time-lapse camera clearly recorded the snow's downhill movements. This can lead to significant differences in peak snow cover thickness between the toe and top. Figure 8 indicates that the thickness was $130 \mathrm{~cm}$ at the top and $72 \mathrm{~cm}$ at the toe at Kuromatsunai in 2018/2019. In gentler slopes, however, this was not the case. In the Naganuma site with 1:4 slope, the snow thickness was largely uniform, as described earlier. The snow 
accumulation at the Kitahiroshima site was affected by two other factors. One is the dumping of snow from the expressway as part of snow removal work, which led to much more significant snow cover in the upper part of the slope (E, F, G and H in Figure 8). The lower part of the slope (A, B, C and D) was likely to be affected by the tree canopy, which covered only the lower part.

Some methods to estimate snow cover evolution based on the precipitation data and the air temperature are documented in the literature (e.g. Gustafsson et al., 2001). These methods have been proposed on the premise that snow cover data are not always available in weather stations. However, the lessons from the three sites point to the fact that each slope is subject to its own special factors, and it is difficult to make an accurate estimate based solely on physically-based or empirical equations.

\subsection{Pore water pressure responses to snow melt}

Most of the snow cover data indicated clear peaks, seen typically in February. The pore water pressure behaviour was distinctly different before and after these peaks. Figure 8 shows a typical example of pore water pressure responses, observed at the Kuromatsunai site in the winter 2018/2019. Since a continuous snow cover was formed at the beginning of December, the pore water pressure kept decreasing, indicating no supply of water from the surface. The surface boundary condition during this period can be considered undrained. When the snow cover depth registers a peak, the pore water pressure started suddenly increasing after a delay, $t_{\mathrm{d}}$. Interestingly, the value of $t_{\mathrm{d}}$ was considerably different at the top and toe, possibly due to the difference in the snow cover depth.

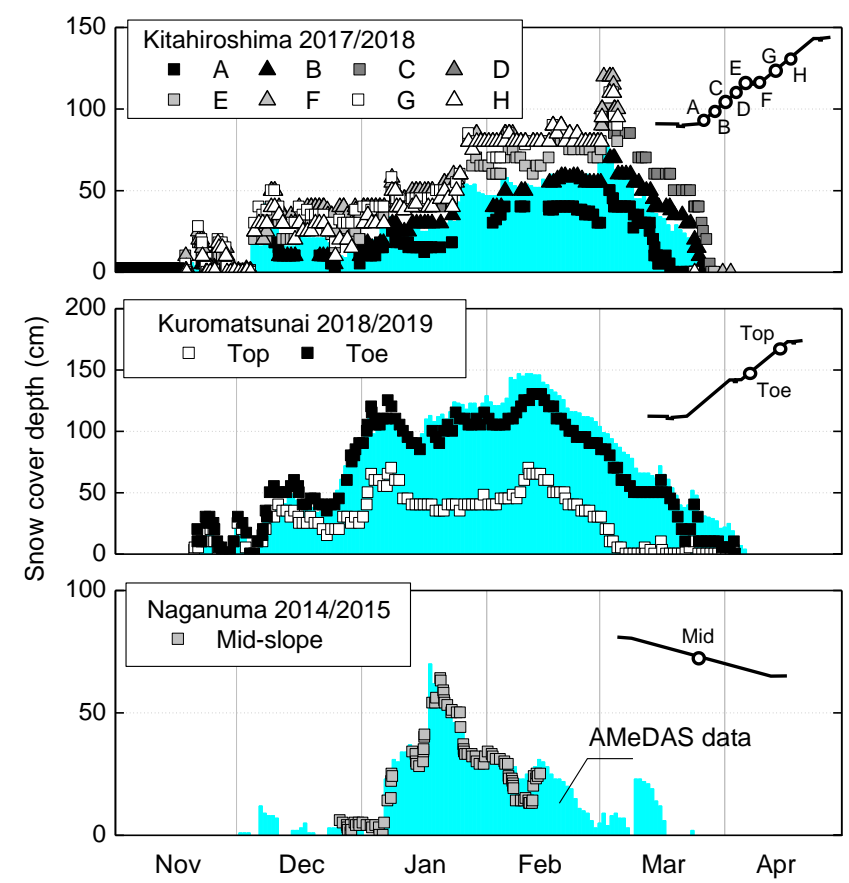

Fig. 7. Examples of snow cover evolution observed on slope surfaces, shown with AMeDAS data.

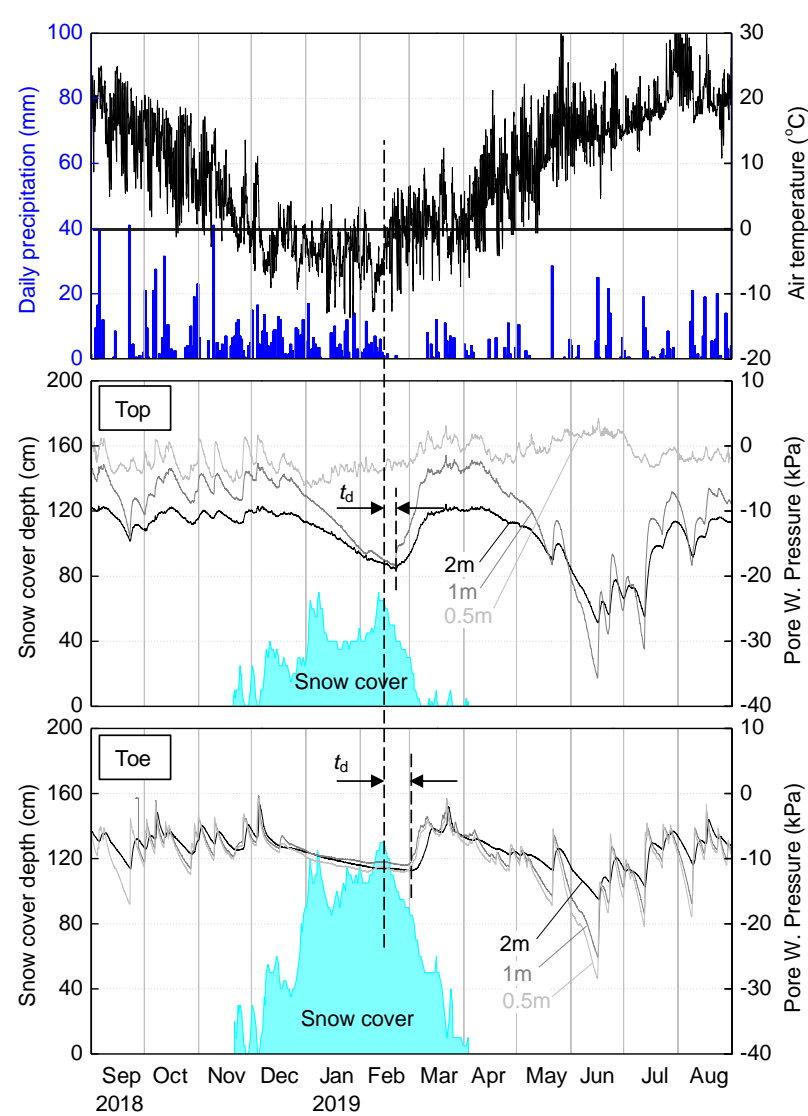

Fig. 8. Examples of ground pore water pressure responses against snow cover variations.

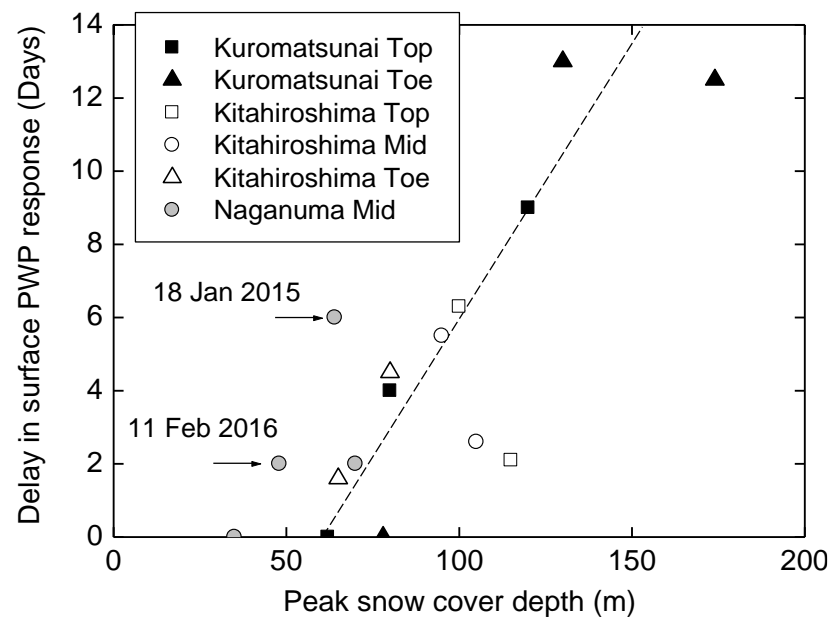

Fig. 9. Delay in ground surface pore water pressure response against date on which peak snow cover was seen.

The above observation led the authors to review all the winter data obtained at the three sites. In most of the cases, the peak snow cover and the abrupt increase of the pore water pressure were clear, and the value of $t_{\mathrm{d}}$ was well-defined. The measured delay in the pore water pressure response, $t_{\mathrm{d}}$, against the snow cover peak is plotted against the peak snow cover depth is plotted in Figure 9. An interesting feature in the trend is that the delay only exists when the peak snow cover exceeds about $60 \mathrm{~cm}$. The two points indicated by arrows in 


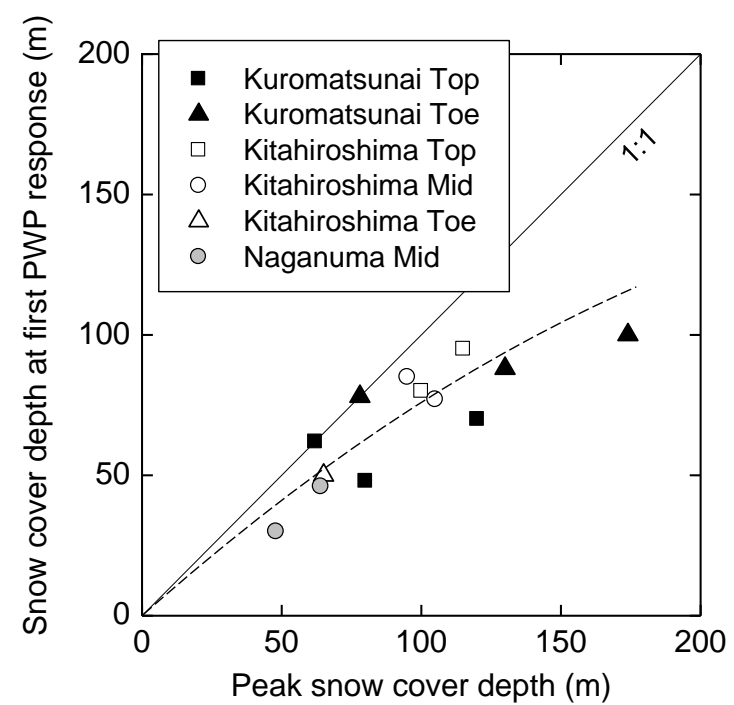

Fig. 10. Delay in ground surface pore water pressure response against date on which peak snow cover was seen.

Figure 9 are off the trend line probably because the snow cover peak dates were exceptionally early, and are not representative of true beginning of the snow melt period.

A similar but possibly more meaningful way of relationship is found by looking at the delay $t_{\mathrm{d}}$ against the snow cover depth remaining at the time of first pore water pressure response. This is shown in Figure 10, and the trend is more unique than seen in Figure 9. Almost the immediate response of the surface pore water pressure when the snow cover is thin, or the non-proportionality seen in Figure 9, implies that the hydraulic conductivity of snow is not the main factor to cause the delay. Meanwhile, the recorded snow temperature was warmer than $-3^{\circ} \mathrm{C}$ at all the depth, and simple calculation based on water heat capacity, latent heat and typical snow density $\left(300-500 \mathrm{~kg} / \mathrm{m}^{3}\right)$ show that regelation of all the water melted at the top cannot be possible by heat transfer between melted snow and remaining snow. A remaining factor, water retention, is likely to play a major role in explaining the curve shown in Figure 10.

\section{CONCLUSIONS}

This study presented evolution of snow cover depth and ground pore water pressure responses to it in three different slopes in Hokkaido, Japan. Once a continuous snow cover is formed, the ground surface boundary condition is undrained, even when the ground surface remains unfrozen. A particular attention was paid to how the ground surface pore water pressure response was delayed when a thick snow cover was present, as the snow melted at the surface travels downward through the snow cover. The data from the three sites were reviewed and a correlation was found between the delay and the peak snow cover depth. The relationship suggests that water retention, rather than low hydraulic conductivity or regelation by heat exchange with remaining snow, is the possible main cause of the delay. The relationship shown in Figure 10 may be easily incorporated into seepage analysis combined with rule-of-thumb snow melt models.

\section{ACKNOWLEDGEMENTS}

The data in this study were obtained in multiple projects; Nexco East SILaWay project, JSPS Kakenhi Grant-in-Aid (16H02360 and 16H04405). The authors are grateful for these fundings.

\section{REFERENCES}

1) Anderson, E. A. (1976): A point energy and mass balance model of a snow cover. NOAA Technical Report NWS 19, U.S. Department of Commerce, National Oceanic and Atmospheric Adminstration, National Weather Service.

2) Aoki, T., Hatakeyama, O. and Hashimoto, H. (2019): The influence that snow melting water gives to a change of the road embankment and examination of spring snowmelt period, JGS Hokkaido Technical Report 59, 211-214. (in Japanese)

3) GEO-SLOPE International Ltd. (2019): Snow melt with the land climate boundary condition, www.geo-slope.com

4) Gustafsson, D., Stähli, M. and Jansson, P. E. (2001): The surface energy balance of a snow cover: comparing measurements to two different simulation models, Theoretical and Applied Climatology, 70(1), 81-96.

5) Ishikawa, T., Tokoro, T. and Miura, S. (2015): Geohazard at volcanic soil slope in cold regions and its influencing factors, Sixth Japan-China Geotechnical Symposium, Sapporo, JGS Special Publication, 1(1), 1-20.

6) Kuushisto, E. (1980): On the values and variability of degree-day melting factor in Finland, Nordic Hydrology, 11, 235-242.

7) Nishiie, S., Nishimura, S. and Yamazoe, N. (2019): Longand short-term pore water pressure variations in sandy river dike interpreted with 1- and 2-phase seepage flow analysis, 7th Asia-Pacific Conference on Unsaturated Soils, AP-UNSAT2019, Nagoya, 648-653.

8) Nguyen, B. T., Ishikawa, T., Murakami, T. (2019): Numerical analysis of in-situ water content and temperature variations due to effects of grass, 7th Asia-Pacific Conference on Unsaturated Soils, AP-UNSAT2019, Nagoya, 660-668.

9) Nishimura, S., Tokoro, T., Yamada, T., Izumi, N. and Rivas, M. F. (2015): A case study of long- and short-term hydraulic state changes in embankment in Hokkaido, Sixth Japan-China Geotechnical Symposium, Sapporo, JGS Special Publication, 1(7), 34-39.

10) Nishimura, S., Tokoro, T. and Rivas, M. F. (2016): Predicting pore water pressure variations in embankments due to evapotranspiration and precipitation, JGS Hokkaido Technical Report, 56, 339-348.

11) Subramanian, S. S., Ishikawa, T., Tokoro, T. (2017): Stability assessment approach for soil slopes in seasonal cold regions, Engineering Geology, 221, 154-169.

12) The SoilVision Systems Ltd. (2019): SVFLUX Theory manual.

13) Takayanagi, T., Miyashita, Y., Yuasa, T. and Keyaki, T. (2019): Verification of topography and soil condition of slope where disaster occurred during snowmelt season in railway, Japanese Geotechnical Journal, 14(2), 123-139. (in Japanese) 